\title{
Threads of Tradition: Koorai Nadu Saree
}

\author{
Chet Ram Meena ${ }^{1 *}$ and T Janani ${ }^{2}$ \\ ${ }^{1}$ Department of Textile Design, National Institute of Fashion Technology, India \\ ${ }^{2}$ Department of Masters of Design Space, National Institute of Fashion Technology, India
}

*Corresponding author: Chet Ram Meena, Assistant Professor, Department of Textile Design, National Institute of Fashion Technology, Mumbai, India

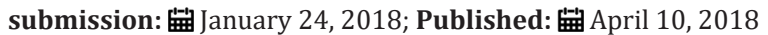

\begin{abstract}
Selection of saree for the occasion of marriage is an art. Saree is considered to be an asset and it is gifted as an heirloom by mother to her newly married daughter, passing down to the future generations as a tradition. Each caste and community of south India has their own colour and style of draping saree for Mangalsutra. Koorai nadu saree is a kind that were meant only for the bride for the occasion of her marriage. It is one of the ancient sarees of Tamil Nadu and only skilled weavers can weave this type of saree. The change in trend and fashion has led to the decline in the demand for this saree. This review paper reveals about the history, culture and present scenario of the Koorai nadu saree.
\end{abstract}

Keywords : Saree; Check/Stripes; Weaves; Silk; Mangalsutra

\section{Introduction}

Though there are different types of religious sensibilities that have prevailed in India for centuries, especially for marriage ceremonies and rituals, these customs and habits differ from religion to religion. The customs adopted by each and every community in the respective states of India have carried different types of rituals for a long period centuries old. Still these customs keep on changing according to needs, conveniences, life styles, livelihood, standard of living, technology, etc. In earlier days, about 100 years back, most of the marriages of different castes and communities in Tamil Nadu were celebrated for a minimum period of 6-7 days. Dowry System: the bride's side of the family gives dowry to the bridegroom's side conversely; it is the bounded duty of the family of the bridegroom to make offerings in the form of draperies including silk saree, blouses, sacred thread (Thali), and ornamental jewels to be worn by the bride right at the time of marriage ceremony [1]. The bride should also wear one sacred saree known as "Koorai Pudavai," based on traditional beliefs. This saree is worn by few casts of Hindu Community of Tamil Nadu. Ancient saree varieties of Tamil Nadu, including Kandangi, Sungudi, Chinnalampatti and Koorai Nadu, were popular decades ago. Weavers skilled in making these traditional sarees are very few. The "Koorai Nadu Saree" specialty is the mix of separate yarns of silk and cotton in both warp and weft and the Mayiladuthurairegion is home to this variety.

\section{History}

Kurai means cloth and Kura means of clothes or thick clothes. Kornad is a corruption of kurai nadu, a place where cloth is manufactured [2-4]. Koorai nadu was part of Chola Nadu and cotton rich clothes were prepared at that time. So during this period there was much demand for the koorai saree. It is also said that the term "Koorai" or "Kurai" emerged owing to the fact that the garment is covering the human body, especially the female body, completely. But, today the Koorai saree has the meaning of bonding Mangalsutra in the Marriage Ceremony of Women. Though it has little traditional literature as to its roots, it vividly shows that the awareness of the Koorai saree has been in existence for decades and has a special place in the minds of women in the society at large [5]. During the special days in "Koorai Nadu", it might have been a trend to buying textiles/dresses during marriage celebrations. Over the period, whatever saree was used by the bride could have been considered as Koorai Saree. There is a belief behind the wearing of Koorai Nadu saree by bride during the marriage that it is a sign of long lasting marriage.

\section{Geographical location}

Mayiladuthurai, formerly known in Sanskrit as Mayuram, is a town in Nagapattinum district of Tamil Nadu in South India. It is the headquarters of the Mayiladuthurai taluk. The town is located at a distance of $60 \mathrm{~km}(37 \mathrm{mi})$ from the district headquarters Nagapattinum and $281 \mathrm{Km}(175 \mathrm{mi})$ from the state capital. Mayiladuthurai Chennai is known for the Mayuranathaswami Temple.

Mayiladuthurai was ruled by medieval Cholas and subsequently ruled by various dynasties including the Vijayanagar Empire, Delhi Sultanate, Thanjavur Nayaks, Thanjavur Marathas and the British Empire. Mayiladuthurai was a part of the erstwhile Tanjore district until India's independence in 1947 and Thanjavur district until 1991 and subsequently a part of the newly formed Nagapattinum 
district. The town is known for agriculture, metal working and weaving. The region around Mayiladuthurai has considerable mineral deposits [6].

Mayiladuthurai is administered by a municipality established in 1865 . As of 2008, the municipality covered an area of $11.27 \mathrm{~km}$ $2(4.35 \mathrm{sq} \mathrm{mi})$ and had a population of 85,632 . Mayiladuthurai comes under the Mayiladuthurai assembly constituency which elects a member to the Tamil Nadu Legislative Assembly once every five years and it is a part of the Mayiladuthurai constituency which elects its Member of Parliament (MP) once in five years [7]. Roadways are the major mode of transportation to the town and it also has rail connectivity. The nearest seaport, Karaikal port, is located $40 \mathrm{~km}(25 \mathrm{mi})$ from Mayiladuthurai, while the nearest airport, Tiruchirappalli International Airport, is located 130KM (81mi) from the town.

\section{About the koorai nadu saree}

The name koorai was derived from the name of the place "koorai Nadu" itself. Koorai nadu sarees are nine yard sarees which are made out of plain cotton as well as cotton and silk mix. These sarees generally have checks and a striped pattern. It is also said that that a similar kind of saree was manufactured in south Karnataka at Anekal and Kollegal during the reign of Hyder Ali in 1750 AD. Koorai nadu sarees consist of silk and cotton both on warp and weft. The peculiar characteristic of this saree is the formation of cotton checks by the interlacement of warp and weft during weaving and this can be woven only by an experienced weaver.

\section{Features of koorai nadu saree}

The distinctive feature of an older Koorai nadu saree is the double side pallu which has a contrasting colour to that of the body. Historically, other weaving clusters of Tamil Nadu also tried to mimic the Koorai Nadu sarees. Koorai nadu saree was also woven in Kanchipuram, Kumbakonam, Arani and Salem. The saree was made out of silk and zari with motifs in the borders and checks in the body. The kornad sarees with wide borders are called temple sarees, because they are created and then donated to a temple deity [8]. These sarees are differentiated in different parts of Tamil Nadu and Karnataka based on the border length, the technique that has been used to weave the border and finally the zari and motifs used (Figure 1).

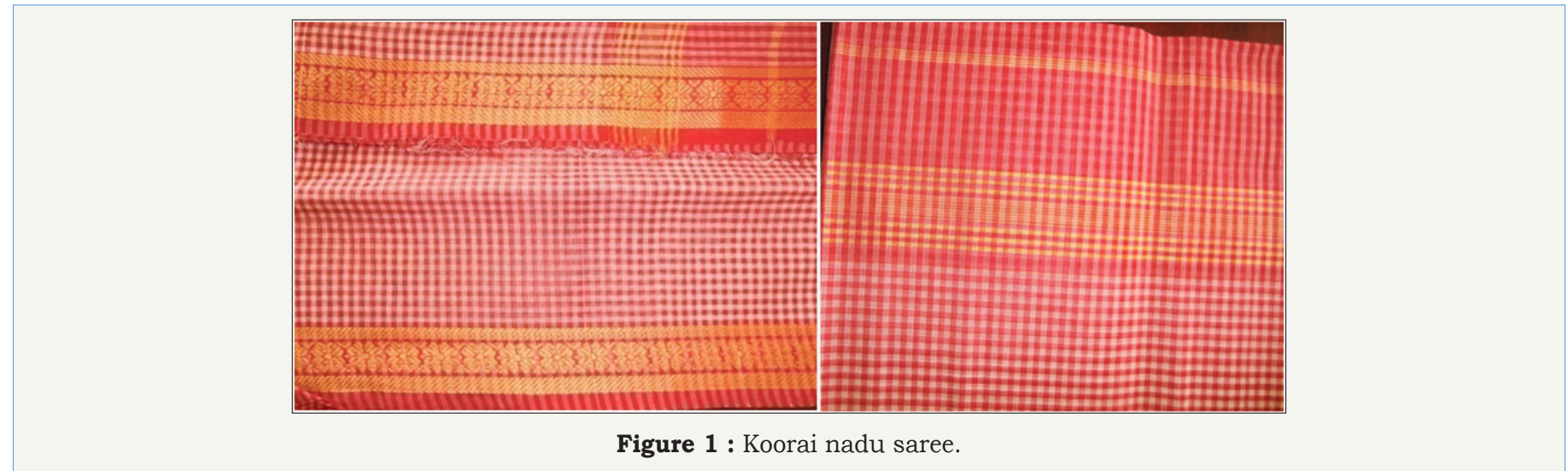

\section{Raw materials for koorai nadu saree}

To produce these Koorai Nadu silk sarees, the required quantity of silk yarn with high quality was procured/purchased from Mysore, Kollegal etc. In India, in the absence of the availability of silk yarn which was produced using the saliva of silk worms, the yarns with high twist which was already dyed were imported from China with the support of Indian government. During the reign of Hyder Ali in $1750 \mathrm{AD}$ sarees were made out of silk and cotton (yellow \& maroon) checked with $16 \mathrm{~s}, 20$ s, and 30 s count, as cotton was coarser at that time, as well as silk yarn [9]. Nowadays the sarees are available in multiple colours and are made out of finer count, that is, $40 \mathrm{~s}, 60 \mathrm{~s}$ and 80s count of cotton and finer count of silk as well. The dye used for silk is synthetic dyes.

\section{Classification of sarees}

\section{Based on material:}

1. Pure cotton (Ancient period)

2. Silk and cotton Mix (Medieval and At present)

\section{Based on checks:}

1. Simple checks crossing each other

2. Solid colour contrasting squares

3. Solid colour checks also known as Aatu Muzhi (Goat's Eye)

4. Most prevalent paalum pazhamum with contrast colours

5. Puliyankottai (Tamarind seed)

6. Kadalai pattani (Pea sized check)

7. Kasakasa (Smallest check of $1 \mathrm{~mm}$ )

8. Two line and three line checks were also common.

Names used for checks in the sari are full of significance which was represented in their own colloquial language (Tamil) since the weavers were illiterate and this allowed for their easy understanding. 


\section{Technical details of the koorai nadu saree}

1. Saree length- 9 yards $(8.1 \mathrm{~m})$ (Traditional) and 6 yards $(5.4 \mathrm{~m})$ (Contemporized)

2. Saree Width- 1.33 yards $(1.21 \mathrm{~m})$

3. Borders- Plain border- Both narrow and broad borders are present.

4. Pallu- Double side pallu was present in the old saree and now only single side pallu is available with Stripes.

\section{Colours}

Traditional colours (natural dyes):

1. Arraku- Maroon

2. Manjal- Yellow

3. Pachai- Green

4. Karuppu-Black

5. Sigappu-Red
Contemporized colours (Chemical dyes): All bright colours are used in the saree (Multi colours)

\section{Weavers community of koorai nadu saree}

The main weavers in Tamil Nadu are kaikolars, also known as sengunthar and saliyars. The other major castes are the Saurashtra community who are immigrants from surat and Devangas who are mainly found in the Coimbatore, Erode, North Arcot and Southern Arcot districts.

\section{Declines in demand of koorai nadu saree}

The Koorai Nadu sarees consisted of simple checks and only few colours were used for traditional designs and patterns were as easily available. The major customer for this saree was from Mysore. When there was demand for silk and the import of silks from China slowly reduced, weavers started buying silk from Mysore. At one point of time the silk merchants started buying the woven saree from the weavers and failed to pay them back. This led to decline of the Koorai Nadu saree and it totally vanished from the traditional list of sarees of Tamil Nadu.

\section{Revival of the koorai nadu saree}

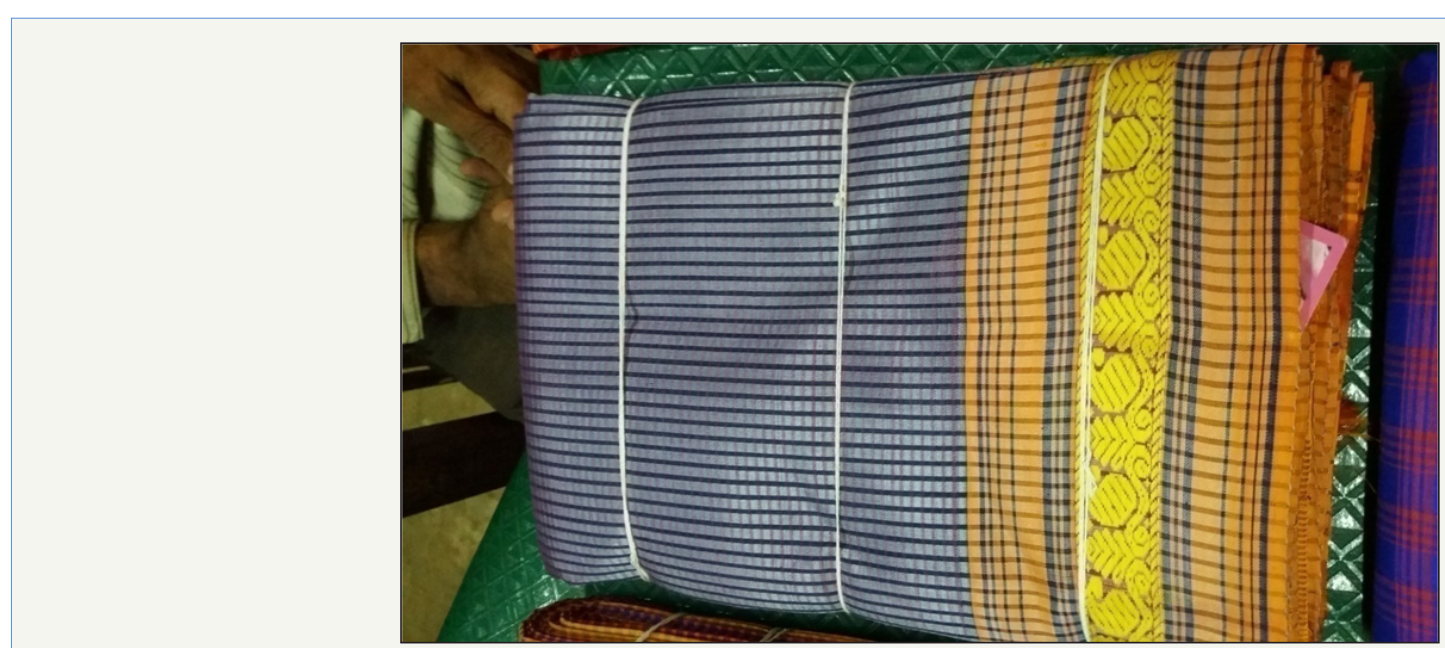

Figure 2 : Koorai nadu sarees with colour variations.

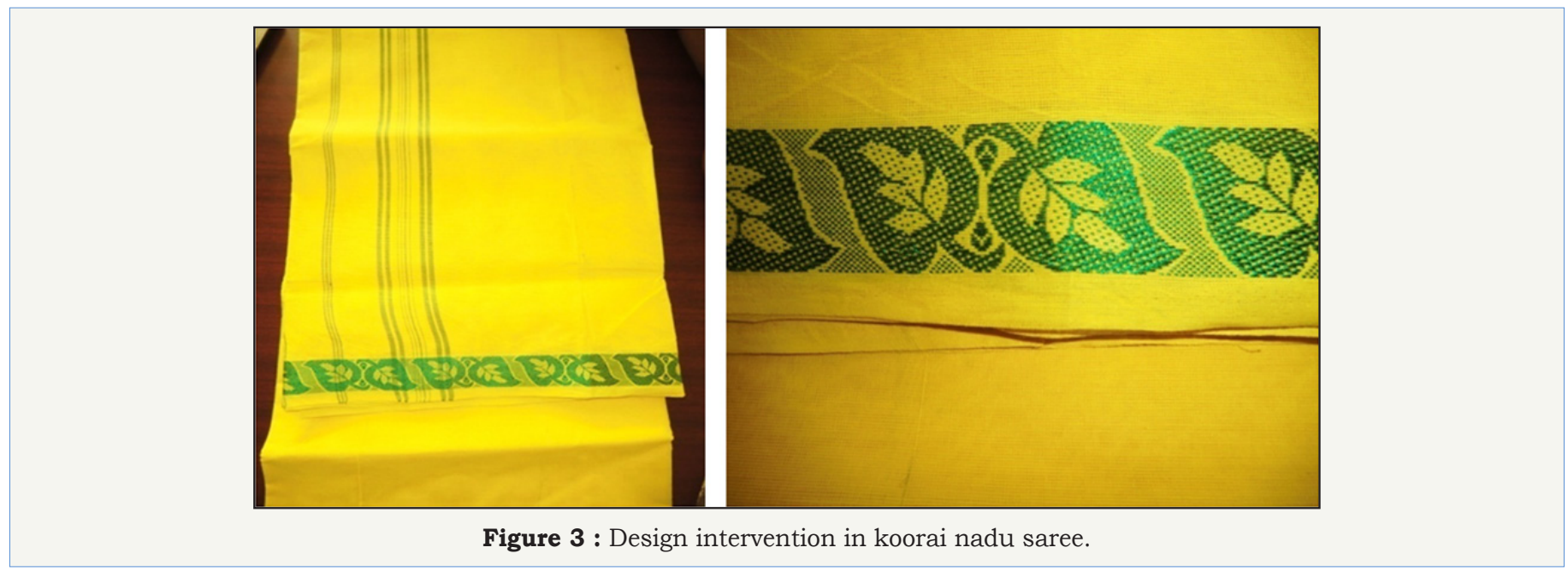


In order to save this craft from dying, Co-Optex, a Tamil Nadu handloom weavers' society in Chennai has taken the initiative to revive this craft so that at least 5 sarees are woven every month. Slowly demand has started increasing but the majority of weavers who are there at present are women who weave it only a few hours a day as the income given to them is poor and so they prefer doing another job everyday and coming later to the day to the society to weave [10]. Koorai Tex is a society in Mayiladuthurai where, for instance, 75 looms existed in1958, and now there are just 5 looms left. At present the koorai tex society is under Co-Optex (Figure 2 \&3).

\section{Production process of koorai nadu saree}

Design development: The designs for revived saree are designed by the Design Studio of Co-Optex.

Procurement of yarns: Both cotton and silk yarns are provided by Tanjore Co-Optex and the silk is in the raw form. Dyeing of silk alone is done in the koorai tex society by local dyers.

Loom: Since the sarees consist of only checks and stripes a normal frame loom is used.

Warping and knotting: Based on the design card the warp beam is prepared and the knotting process is carried out. The borders have similar strands of yarn and the yarn colour changes on the body.

Weaving: The weavers have to move their hands and legs 13,000 times to complete a saree. Each saree takes a week time to complete. The shuttle is inserted by hand wherever the checked effect is necessary.

\section{Current scenario}

The market and demand for this saree has slowly increased. But the weavers able to create this saree are small in number. The sarees are available in vibrant multi colours. The price range of saree varies from Rs.4000-Rs. 11,000.

\section{Conclusion}

Owing to the technical developments in the textile industry, the Koorai Nadu saree market currently faces a severe slump and suffered heavy income losses. In view of this, all the families who are involved in the manufacture of Koorai Nadu sarees have gradually shifted to many other varied professions to earn their day-to-day living and their subsequent generations have also lost interest in this handloom product. Thus the handloom weaving industry had lost its identity in the society. In this paper, the author has tried to spread awareness about the Koorai Nadu saree and to highlight the need for provision of reasonable wages to handloom weavers by way of allocation of adequate funds by the Government[s], professional organizations, business magnates, or Vyapar Jambhavans for the manufacture of these handloom silk sarees. If this can be done in the right spirit, their manufacture can be rejuvenated and enjoy a renaissance in the state, national, and global textile markets in the years to come.

\section{References}

1. Burrow T (1961) A dravidian etymological dictionary. Oxford University, UK.

2. Pillai RP (1974) Words and their significance and Tamil, literary and colloquial. Madras, India.

3. Lynton L, Singh SK (1995) The sari: styles, patterns, history, techniques. Thames and Hudson, London, UK.

4. Waghorne J P (1999) The diaspora of the gods: Hindu temples in the new world system 1640-1800. The Journal of Asian Studies 58(3): 648-686.

5. Ramani S (2002) Sari, the kalakshetra tradition. Craft Education \& Research Centre, Kalakshetra Foundation, Chennai, India.

6. Bhagavathi K (2003) Tamizhar Aadaigal ( $2^{\text {nd }}$ edn), International Institute of Tamil Studies CPT campus, Chennai, Tamil Nadu, India.

7. Katiyar VS (2009) Indian saris: traditions, perspectives, design. Wisdom Tree, in association with National Institute of Design, New Delhi, India.

8. Chishti RK, Singh M, Kelkar R (2013) Saris of India: tradition and beyond. Roli Books, Lustre Press, New Delhi, India.

9. Arumugam N (2011) Silk sarees of Tamil Nadu. Abhinav Publications, New Delhi, India.

10. Co-optex (2014) Traditional handloom products of Tamil Nadu. Chennai, Tamil Nadu Handloom Weavers Co-operativesociety Ltd, Chennai, India.
Creative Commons Attribution 4.0 International License

For possible submissions Click Here

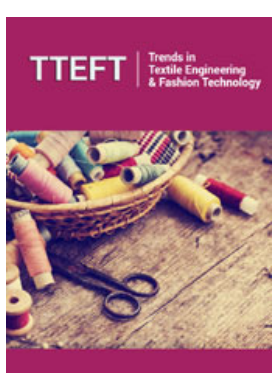

Trends in Textile Engineering \& Fashion Technology

\section{Benefits of Publishing with us}

- High-level peer review and editorial services

- Freely accessible online immediately upon publication

- Authors retain the copyright to their work

- Licensing it under a Creative Commons license

- Visibility through different online platforms 